\title{
Experimental investigation on the bamboo-concrete filled circular steel tubular stub columns
}

\author{
D. Gan ${ }^{\mathrm{a}, \mathrm{b}}$, T. Zhang ${ }^{\mathrm{a}, \mathrm{b}}$, X. Zhou ${ }^{\mathrm{a}, \mathrm{b}}$ and Z. He $\mathrm{He}^{\mathrm{a}, \mathrm{b} *}$
}

\author{
${ }^{a}$ Key Laboratory of New Technology for Construction of Cities in Mountain Area (Chongqing University), \\ Ministry of Education, Chongqing 400045, China \\ ${ }^{b}$ School of Civil Engineering, Chongqing University, China \\ *Ziqi He, e-mail address: heziqi@cqu.edu.cn
}

\begin{abstract}
Concrete-filled steel tubes have been widely used all over the world due to their superior structural behaviour. To promote the use of ecofriendly materials and to reduce the use of concrete, this paper presents an innovative type of composite column, which can be referred as bamboo-concrete filled steel tubes. In this kind of column, concrete filled in the space between the external steel tube and the inner raw moso bamboo. Bamboo-concrete filled steel tubes inherit the merits of concrete-filled steel tubes such as high load-bearing capacity and ductility performance. Besides, global buckling behaviour of a bamboo column due to its relatively large slenderness can be significantly improved, and the bamboo column with nodes could provide confinement to the infilled concrete.

This paper investigated the composite effect of bamboo-concrete filled steel tubular stub columns subjected to axial compression. In addition, concrete-filled double-skin steel tubular stub columns and hollow concrete-filled steel tubular stub columns were also tested for comparison. The main experimental parameter considered was the diameter-tothickness ratio $(D / t)$ of steel tube. Test results indicated that the composite columns with moso bamboo pipe as inner core elements showed better ductility than the hollow concretefilled steel tubular stub columns. The bearing capacity and ductility visibly increased with decreasing of the $D / t$ ratio.
\end{abstract}

Keywords: Bamboo concrete infill; raw moso bamboo; hollow concrete-filled steel tube; axial compression; concrete-filled double-skin steel tube.

\section{Introduction}

Concrete-filled steel tubes (CFST) have been widely used due to their superior mechanical properties. Steel tube can delay cracking of the infilled concrete, and the infilled concrete can provide lateral support to outer steel tube continuously. Thus, local buckling of thinwalled steel tubes can be delayed.

Based on concrete-filled steel tubes, some novel composite members were proposed in recent years. Some researchers have studied concrete-filled double-skin steel tubes (CFDST), a new type of concrete-filled steel tubes. Advantages of double-skin concrete-filled steel tubes include: increased section modulus, enhanced global stability and lighter weight. Hsiao et al. [1] experimentally investigated the behaviour of CFST and CFDST columns using ultrahigh-strength steel subjected to combined axial and flexural cyclic loadings. The ultimate member moment capacities were predicted accurately using a proposed simple formulation based on the concept of the superposed strength method. Li et al. [2] experimentally studied concrete-filled double-skin steel tubes under axial load. The behaviour of axially loaded CFDST columns with preload either on the outer tube alone or on both tubes were discussed. It was found that the strength of CFDST column might be decreased moderately when the preload was applied. Yuan and Yang [3] presented a study on the performance of concrete-filled double skin composite tube columns under axially compressive loads using both experimental and numerical methods. The 
composite column investigated consisted of an octagonal steel tube as its outer skin layer, a circle PVC-U pipe as its inner skin layer, and high strength concrete filled in between the two layers. Influences of concrete strength, radius-tothickness ratio, hollow section ratio, and slenderness ratio on the ultimate axial compressive capacity of the composite column were examined.

Apart from the concrete-filled double-skin steel tubes, many experiments have been carried out on hollow concrete-filled steel tube columns because of their less steel consumption and lighter weight. Miyaki et al. [4] presented an experimental study on centrifugal concrete filled steel square tubular stub columns under axial compression. An evaluation formula of compressive strength taking confining effect in was derived from the test results. Ultimate compressive strength of concrete filled steel square tubular columns can be estimated by proposed formula. Wang et al. [5] studied the influence of hollow ratio of hollow concretefilled steel tube columns to load-carrying capacity. The results showed that circular specimens had higher capacities than that of the other cross sectional (quadrilateral, octagonal and hexagonal) specimen. It was indicated that the higher the hollow ratio, the lower the loadcarrying capacity.

Ghazijahani et al. [6] proposed a new type of composite member, concrete-filled circular steel tubes with a timber infill. For the specimens with the highest timber to concrete ratio, the capacities were enhanced by about twice the capacity of the hollow steel specimens. It was found that the use of timber as an inner core element in this new composite column yields promising resulted in decreasing the weight and yet enhancing the capacity, ductility, and energy absorption. Concrete-filled circular steel tubes with a timber infill can be a good alternative to concrete-filled double-skin steel tubes.

To promote the use of ecofriendly materials and to reduce the use of concrete, this paper proposes a new kind of composite column, namely bamboo-concrete filled circular steel tube. Bamboo, a natural raw material, is easily obtained and is of high strength/weight ratio [7]. Bamboo pipes can simplify construction comparing with hollow concrete-filled steel tubes and lower steel consumption comparing with concrete-filled double-skin steel tubes. This paper aims to investigate the axial load behaviour of bamboo-concrete filled circular steel tubular stub columns. Load-carrying capacities and ductility were discussed and compared with concrete-filled double-skin steel tubular stub columns and hollow concrete-filled steel tubular stub columns.

\section{Experimental program}

\subsection{Test specimens and materials}

A total of ten specimens, including three concrete-filled double-skin steel tubular stub columns, four bamboo-concrete filled circular steel tubular stub columns and three hollow concrete-filled steel tubular stub columns, were tested to failure under axial compression. All specimens were identified as three types, namely type A, type B and type C, and the schematic diagrams of the three types of specimens are shown in Fig. 1. The external diameter $(D)$ and length $(L)$ of all specimens were the same $(D=240 \mathrm{~mm}$ and $L=720 \mathrm{~mm}$ ). The external diameter $(d)$ of infilled tubes for all specimens was $120 \mathrm{~mm}$. The ratio of length to diameter was three to ensure short column behaviour. Table 1 provides details of all the specimens, where $t_{\mathrm{b}}$ and $t_{\mathrm{s}}$ are the thickness of infilled bamboo pipes and steel tubes, respectively. Material properties of bamboo, concrete and steel tubes are also shown in Table 1.

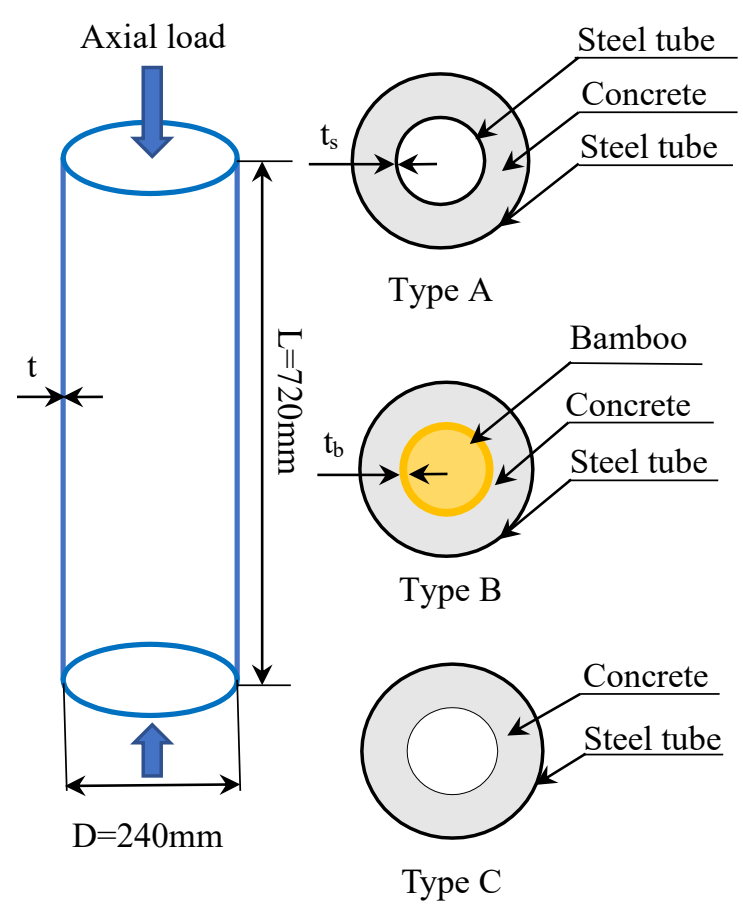

Fig. 1. Schematic drawing of specimens. 
The labeling system of the specimens was the following: taking B6-120-12-1 as an example, the first letter B indicates bamboo-concrete filled circular steel tubular stub columns; similarly, A and $\mathrm{C}$ represent concrete-filled double-skin steel tubular stub column and hollow concrete-filled steel tubular stub column, respectively; the first number 6 is the thickness of outer steel tube; the latter number 120 and 12 respectively show diameter and thickness of the bamboo. It should be noted that two same specimens, i.e. B6-12012-1 and B6-120-12-2, were designed and tested to evaluate discreteness of two bamboo-concrete filled circular steel tubular stub columns.

Table 1. Details of specimens.

\begin{tabular}{lccccccccc}
\hline Specimen & $\begin{array}{c}\boldsymbol{L} \\
(\mathrm{mm})\end{array}$ & $\begin{array}{c}\boldsymbol{D} \\
(\mathrm{mm})\end{array}$ & $\begin{array}{c}\boldsymbol{t} \\
(\mathrm{mm})\end{array}$ & $\boldsymbol{D} / \boldsymbol{t}$ & $\begin{array}{c}\boldsymbol{f}_{\mathrm{cu}} \\
(\mathrm{MPa})\end{array}$ & $\begin{array}{c}\boldsymbol{f}_{\mathbf{y}} \\
(\mathrm{MPa})\end{array}$ & $\begin{array}{c}\boldsymbol{f}_{\mathbf{b}} \\
(\mathrm{MPa})\end{array}$ & $\begin{array}{c}\boldsymbol{d} \\
(\mathrm{mm})\end{array}$ & $\begin{array}{c}\boldsymbol{t}_{\mathbf{s}} \text { or } \boldsymbol{t}_{\mathbf{b}} \\
(\mathrm{mm})\end{array}$ \\
\hline $\mathrm{A} 2-120-2$ & 720 & 240 & 2 & 120 & 30.1 & 319 & $/$ & 120 & 2 \\
$\mathrm{~A} 4-120-2$ & 720 & 240 & 4 & 60 & 30.1 & 271 & $/$ & 120 & 2 \\
$\mathrm{~A} 6-120-2$ & 720 & 240 & 6 & 40 & 30.1 & 281 & $/$ & 120 & 2 \\
\hline B2-120-12 & 720 & 240 & 2 & 120 & 28.6 & 319 & 60 & 120 & 12 \\
B4-120-12 & 720 & 240 & 4 & 60 & 28.6 & 271 & 60 & 120 & 12 \\
B6-120-12-1 & 720 & 240 & 6 & 40 & 28.6 & 281 & 60 & 120 & 12 \\
B6-120-12-2 & 720 & 240 & 6 & 40 & 28.6 & 281 & 60 & 120 & 12 \\
\hline C2-120 & 720 & 240 & 2 & 120 & 31.2 & 319 & $/$ & 120 & $/$ \\
C4-120 & 720 & 240 & 4 & 60 & 31.2 & 271 & $/$ & 120 & $/$ \\
C6-120 & 720 & 240 & 6 & 40 & 31.2 & 281 & $/$ & 120 & $/$ \\
\hline
\end{tabular}

\subsection{Specimen fabrication}

Steel tubes were fabricated in a factory. Moso bamboo pipes were selected and dried under room circumstance in advance. The moso bamboo pipes were cut in the light of the designed length. As shown in Fig. 2(a), to avoid floating of bamboo pipes during concreting, bamboo pipes or steel tubes were placed, centralized, and clamped inside the tubes. After 28 days of concrete curing, the specimens were ready for testing. Both ends of specimens were polished carefully before the test to have uniform axial load distribution (Fig. 2(b)).

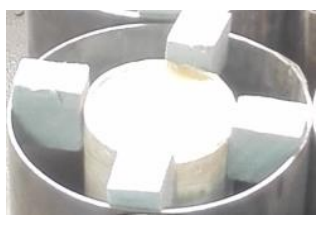

(a) Clamed bamboo.

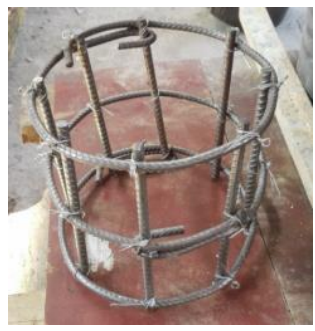

(c) Cage.

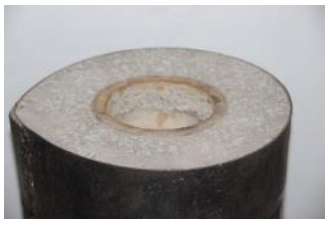

(b) Polished surface.

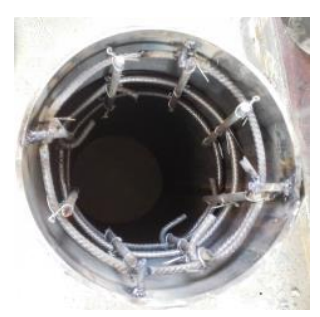

(d) Cage in steel tube.
Fig. 2. Specimen preparation.
To avoid local failure of columns ends, short and discontinuous steel cages were used to enhance the both ends of every column (shown in Fig. 2(c) and (d)). The length of the steel cages was $150 \mathrm{~mm}$. The steel cages could avoid undesired local failure and facilitate the failure in the mid-height region of column. It could be considered that the steel cages do not influence the mechanical properties of columns.

\subsection{Test setup}

A $10000 \mathrm{kN}$ hydraulic compression machine was used to provide axial load. The load was slowly and continuously applied during the test.

The axial load was recorded continuously with a load cell. Four linear variable differential transformers (LVDT) were used to measure axial deformation during the test. Strain gauges were arranged in $90^{\circ}$ intervals to monitor longitudinal and hoop strains of tubes. For all specimens, strain gauges were only arranged at the mid-height of the outer steel tubes. The test setup is shown in Fig. 3. 


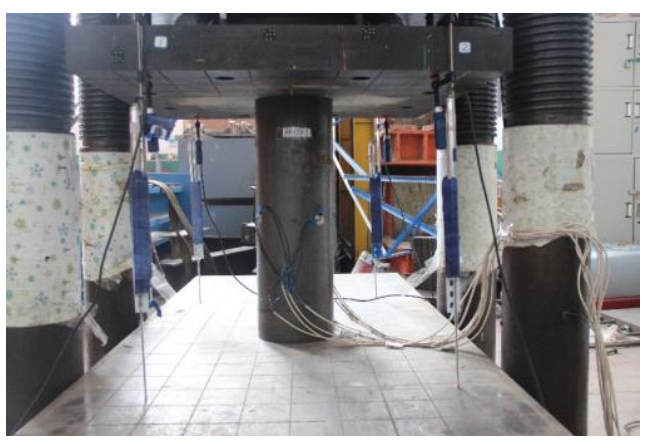

Fig. 3. Test setup and components.

\section{Experimental results and discussion}

\subsection{Test observation and failure}

Fig. 4 shows typical failure modes of five columns at the end of test. It was observed that the specimens with $D / t$ ratio of 120 suffered shear failure. This was because thin-walled circular steel tubes could not prevent the shear failure of concrete filled. In contrast, concrete is crushed or squashed for the specimens with $D / t$ ratio of 40 and 60 , because of a thicker circular steel tube. It was found that there was no visible bucking on steel tube before the peak load for all the specimens. The buckling of all the specimens became obvious when the load fell to about $70 \%-95 \%$ of the peak load. After test, the bamboo of type B specimens sprang back and extended out (nearly $5 \mathrm{~mm}$ ), as can be seen in Fig. 5(a). Buckling of the inner tubes of concrete-filled double-skin tubes and crushed concrete inside the hollow concrete-filled steel tubes were observed after the test, as shown in Figs. 5(b-c).

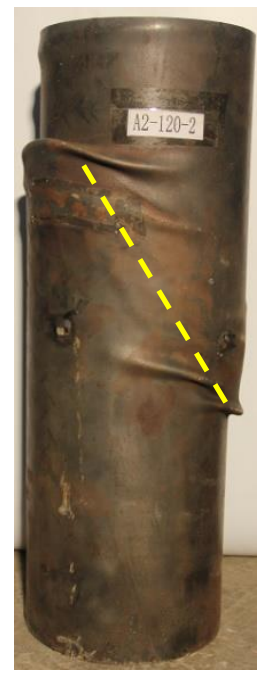

(a) A2-120-2.

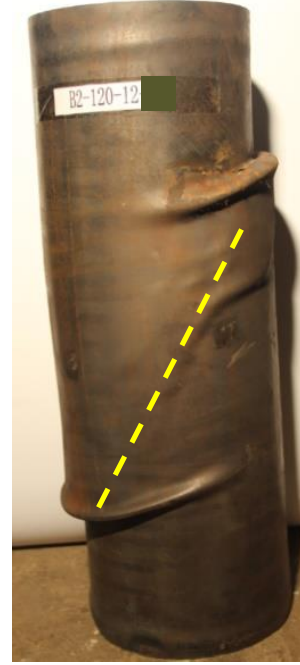

(b) B2-120-12.

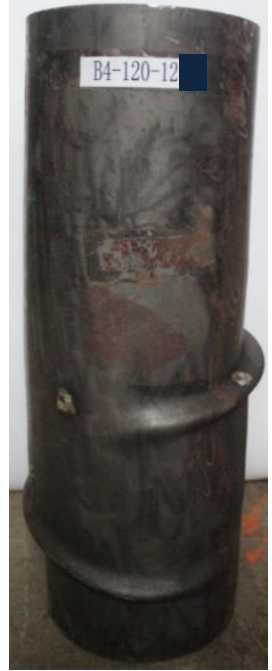

(c) B4-120-12.

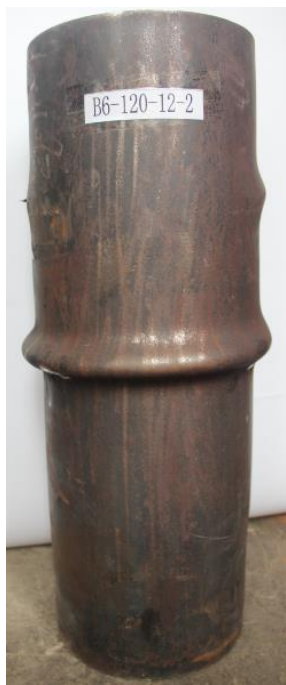

(d) B6-120-12-2.

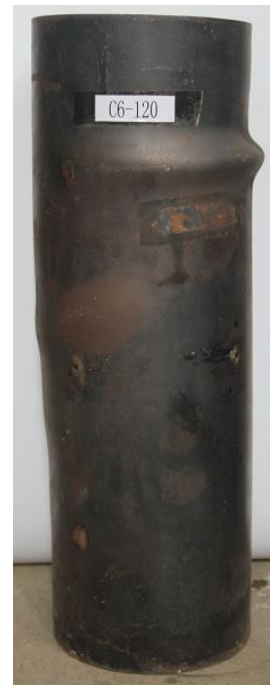

(e) C6-120.

Fig. 4. Failure modes of specimens.
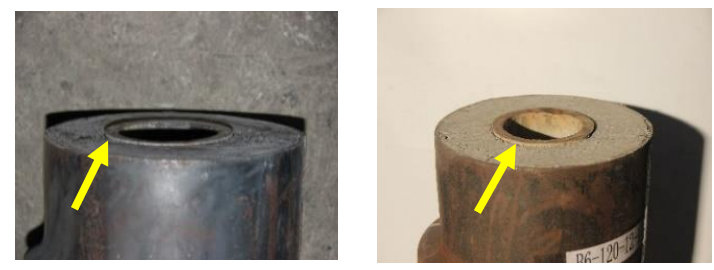

(a) Bamboo sprung back.

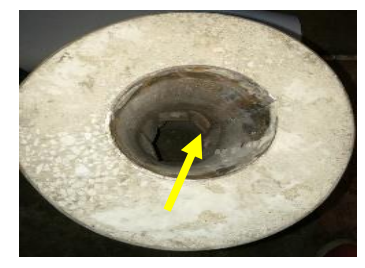

(b) Buckling of inner steel tube.

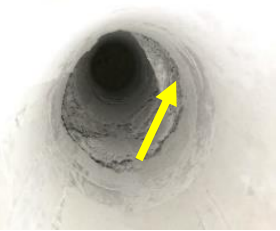

(c) Crushed concrete.

Fig.5. Details after failure. 


\subsection{Axial load-displacement behaviour and capacity}

To compare axial load-carrying capacities of all the specimens, the superposition principle was used in this paper. The predicted load $\left(P_{\mathrm{u}}\right)$ was calculated by Eq. (1), where, $f_{\mathrm{y}}$ is the measured yielding strength of steel tubes; $f_{\mathrm{ck}}$ is characteristic concrete strength. The value of $f_{\text {ck }}$ is determined using $76 \%$ of the compression strength of cubic blocks $\left(f_{\mathrm{cu}}\right) ; A_{\mathrm{s}}$ and $A_{\mathrm{c}}$ are area of steel tube and concrete, respectively.

$$
P_{u}=f_{y} A_{\mathrm{s}}+f_{c k} A_{c}
$$

The prediction $\left(P_{\mathrm{u}}\right)$, the experimental peak load $\left(P_{\text {ue }}\right)$ and $P_{\text {ue }} / P_{\text {u }}$ ratio are shown in table 2. It should be noted that the contribution of bamboo was not included in the calculation for comparison reasons. By doing this, the influence of infilled bamboo on capacities could be showed more obviously through the comparisons of test results between type B and type $\mathrm{C}$ specimens.

The measured axial load-displacement curves of all the specimens are shown in Fig. 6, where the displacement $(\Delta)$ is the average of four values measured by LVDTs. The diameter-to-thickness ratio had significant and similar influence on the

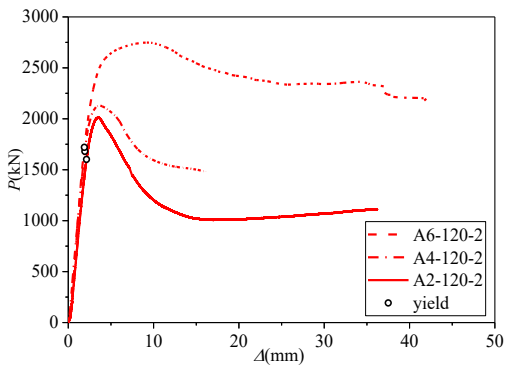

(a) Type A.

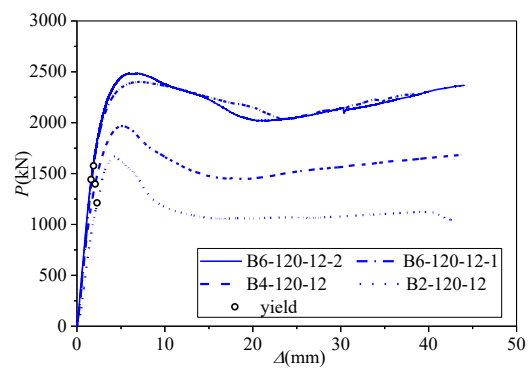

(b) Type B. axial load-displacement curves of all the specimens, and axial load-carrying capacity visibly decreased with increasing $D / t$ ratio. Steel tubes yielded at $70-85 \%$ of the peak load in the pre-peak stage. This showed that steel tubes had been fully used.

Table 2. Load-carrying capacity and ductility.

\begin{tabular}{lcccc}
\hline Specimen & $\boldsymbol{P}_{\mathbf{u}}(\mathrm{kN})$ & $\boldsymbol{P}_{\text {ue }}(\mathrm{kN})$ & $\boldsymbol{P}_{\mathbf{u e}} / \boldsymbol{P}_{\mathbf{u}}$ & $\boldsymbol{D I}$ \\
\hline A2-120-2 & 1733.8 & 2012.1 & 1.16 & 1.65 \\
A4-120-2 & 2024.7 & 2129.0 & 1.05 & 1.92 \\
A6-120-2 & 2467.7 & 2748.3 & 1.11 & 2.74 \\
\hline B2-120-12 & 1424.4 & 1671.5 & 1.17 & 1.61 \\
B4-120-12 & 1729.6 & 1969.2 & 1.14 & 1.93 \\
B6-120-12-1 & 2144.1 & 2400.4 & 1.12 & 3.3 \\
B6-120-12-2 & 2144.1 & 2485.1 & 1.16 & 2.91 \\
\hline C2-120 & 1486.9 & 1724.1 & 1.16 & 1.31 \\
C4-120 & 1767.6 & 1944.7 & 1.10 & 1.59 \\
C6-120 & 2158.1 & 2470.4 & 1.14 & 2.4 \\
\hline
\end{tabular}

Bamboo is a natural material and unavoidable to be inhomogeneous in geometry and physical properties. However, the overall trend of the specimens with the same parameters, for example B6-120-12-1 and B6-120-12-2, showed nearly the same behavior (Fig. 6(b)).

Fig. 6. Axial load-displacement curves of three types of specimens.

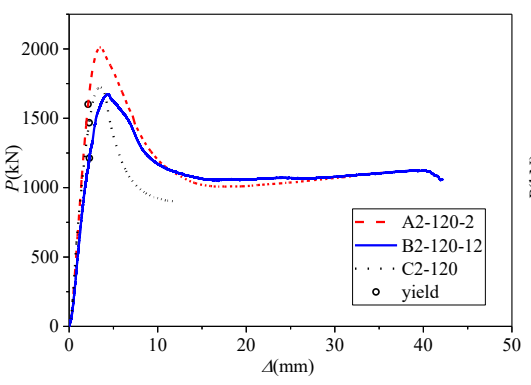

(a) $D / t$ ratio of 120 .

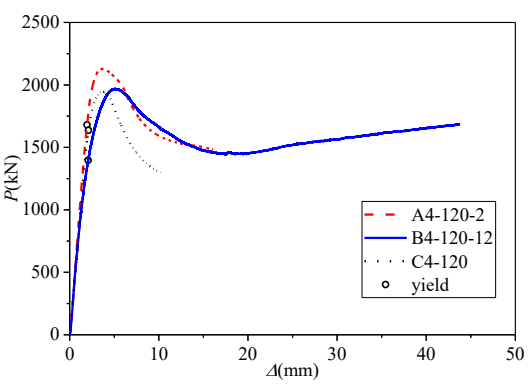

(b) $D / t$ ratio of 60 .

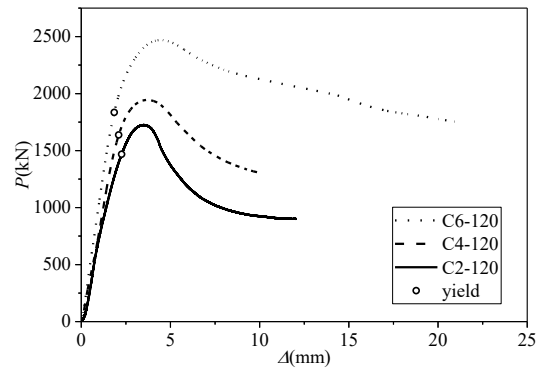

(c) Type C.

Fig. 7. Axial load-displacement curves of different types of specimens. 
Fig. 7 shows the axial load-displacement curves of specimens in types A, B and C with the same $D / t$ ratio. The specimens with steel tube infill (type A) had the largest peak loads compared with the other two types of columns. Loads of the specimens with bamboo infilled (type B) decreased slower than those of the other two types of columns after the peak load, indicating a better ductility performance. While the bamboo pipes did not improve the peak load apparently, this may be due to the small deformations at the peak loads. Thus, strength of bamboos was not utilized adequately. In addition, there is a slight gap between infilled bamboo and concrete due to water loss from bamboo, so the slenderness ratio of bamboo is large at the beginning of test. The infilled bamboo did not work until after the peak load, when the concrete was in direct contact with the bamboo pipe due to the development of concrete cracks.

\subsection{Ductility}

The ductility index $(D I)$ in [8] is adopted to quantify section ductility. It is expressed as

$$
D I=\frac{\Delta_{85 \%}}{\Delta_{\mathrm{u}}}
$$

where the $\Delta_{\mathrm{u}}$ is the displacement at the peak load, and the $\Delta_{85 \%}$ is the displacement when the load falls to $85 \%$ of the peak load.

The values of $D I$ of all the specimens are listed in table 2, and they are plotted versus $D / t$ ratio in Fig. 8. It was found that the ductility decreased with increasing $D / t$ ratio. The bamboo-concrete filled circular steel tubes had high ductility, thanks to the three materials interacted.

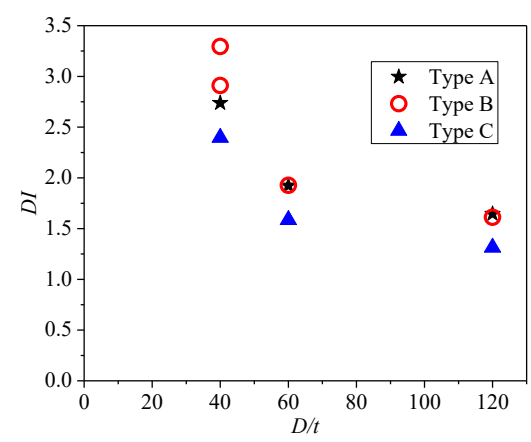

Fig. 8. $D I$ versus $D / t$ ratio.

In bamboo-concrete filled circular steel tubes, the steel tube provided lateral restraint to the concrete and delayed cracking of the concrete. In turn, the concrete provided lateral support for steel tube to delay the buckling of steel tube, and the bamboo pipe provided lateral restraint for the concrete. This mechanism is similar to concretefilled double-skin steel tubes columns.

It was found that the effect of bamboo on ductility would be more significant as the thickness of external steel tubes increased. With the increasing thickness of the outer steel tubes, the transverse deformation of concrete had been restricted more effectively, and it had to be more inclined to develop inward. Thus, the restraint effect of infilled bamboo for concrete became more obvious and the infilled bamboo could work together with the infilled concrete. However, local buckling of an inner steel tube weakened the restraint effect for the double-skin arrangement. Thus, the loads of type A specimens dropped a little faster than those of type B specimens at the end of the test when $D / t$ ratios were 40 and 60 .

It was observed that the axial load-carrying capacities of B6-120-12-1 and B6-120-12-2 with $D / t$ ratio of 40 had distinct increasing, even close to the peak load values at the end of the test, as seen from Fig. 7(c). This also definitely suggests the infilled bamboo provided superior ductility for such composite elements.

\subsection{Strain response}

The relationship between load and strain is depicted in Fig. 9, where the $\varepsilon_{\mathrm{v}}$ and $\varepsilon_{\mathrm{h}}$ are the longitudinal and hoop strains of steel tubes, respectively. Both $\varepsilon_{\mathrm{h}}$ and $\varepsilon_{\mathrm{v}}$ are the averages of four measurements obtained by the strain gauges.

It was indicated that all specimens had similar feature in the elastic stage. The hoop strain and longitudinal strain are proportional to the load and the ratio of longitudinal strain to hoop strain was almost constant in the elastic stage. The reason may be attributed to the fact that there was little interaction between steel tube and concrete, concrete and inner pipe in the elastic stage, and the three components worked independently in this stage. The hoop strain increased faster after the peak load, this was the result of interaction between concrete and steel tube. 


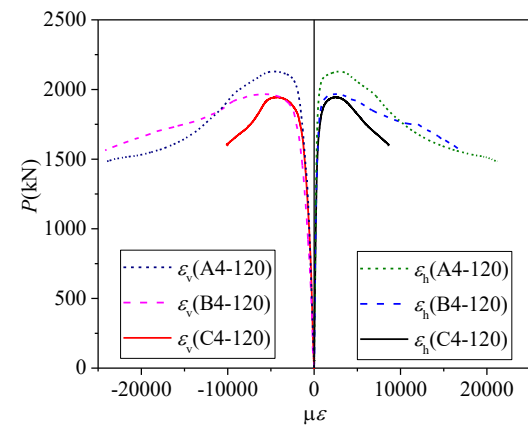

Fig. 9. Strain responses of specimens $(D / t=60)$.

\section{Conclusions}

This paper presents an experimental investigation on a novel kind of composite column, namely bamboo-concrete filled circular steel tubular stub column, which could promote the use of ecofriendly materials and reduce the use of concrete. The ratio of diameter to thickness of steel tube was the main test parameter. In addition, concrete-filled doubleskin steel tubular stub columns and hollow concrete-filled steel tubular stub columns were also tested for comparison. Through analysis and evaluation of the test results, several conclusions can be drawn.

1) With decreasing of $D / t$ ratio, the axial load-carrying capacity and ductility of all the three types of stub columns visibly increased. Ductility of bamboo-concrete filled circular steel tubular columns was much better than that of hollow concretefilled stub columns. Moreover, the ductility of this new kind of composite column was similar with concrete-filled double-skin steel tubular stub column when $D / t$ ratio was greater than 60 . The effect of bamboo on ductility would be more obvious as the thickness of external steel tubes increased.

2) Bamboo pipes almost did not improve the peak loads. This might be due to the strength of bamboos was not utilized, because of the small deformations at the peak loads. Further research is still needed to clarify this.

\section{References}

[1] Hsiao PC, Hayashi KK, Nishi R, Lin XC, Nacashima $M$. Investigation of concrete-filled double-skin steel tubular columns with ultrahighstrength steel. Journal of Structural Engineering ASCE 2014; 141(7): 04014166.

[2] Li W, Han LH, Zhao XL. Axial strength of concrete-filled double skin steel tubular (CFDST) columns with preload on steel tubes. Thin-Walled Structures 2012; 56(4): 9-20.

[3] Yuan WB, Yang JJ. Experimental and numerical studies of short concrete-filled double skin composite tube columns under axially compressive loads. Journal of Constructional Steel Research 2013; 80(1): 23-31.

[4] Miyaki S, Matsui C, Tsuda K, Hatato T, Imamura T. Evaluation formula of compressive strength of centrifugal concrete filled steel square tubular columns. Journal of Structural Engineering B 1997; 43: 581-586.

[5] Wang HW, Xu GL, Zhong ST. Study on influence of hollow ratio to bearing capacity of $\mathrm{H}-\mathrm{CFST}$ (in Chinese). Engineering Mechanics 2007; 24(10): 112-118.

[6] Ghazijahani TG, Jiao H, Holloway D. Concretefilled circular steel tubes with a timber infill under axial compression. Journal of Structural Engineering 2017; 143(7): 04017037.

[7] Xiao Y, Yang RZ, Shan B. Production, environmental impact and mechanical properties of glubam. Construction \& Building Materials 2013; 44(3): 765-773.

[8] Han LH. Tests on stub columns of concrete-filled RHS sections. Journal of Constructional Steel Research 2002; 58(3): 353-372. 